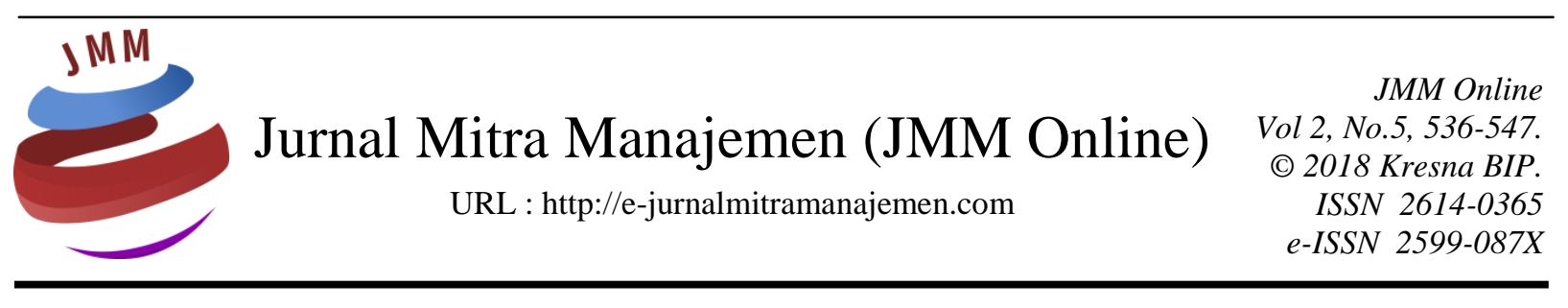

\title{
PENGARUH KUALITAS LAYANAN, HARGA, KEPUASAN PELANGGAN SERTA LOYALITAS PELANGGAN PADA PT KAI KOMMUTER JABODETABEK STASIUN DEPOK JAWA BARAT
}

\author{
Syahrial Addin ${ }^{1)}$, Putie Maharani Basa ${ }^{2)}$, Nurullah Sururi Afif ${ }^{3)}$ \\ AMIK BSI Jakarta ${ }^{1)}$, AMIK BSI Bogor ${ }^{2)}$, AMIK BSI Jakarta ${ }^{3)}$
}

INFORMASI ARTIKEL

Dikirim : 21 September 2018 Revisi pertama : 22 September 2018 Diterima : 23 September 2018

Tersedia online : 28 September 2018

Kata Kunci : Kualitas Pelayanan, Harga, Kepuasan, Loyalitas Pelanggan

Email : syahrial.sra@bsi.ac.id ${ }^{1)}$, putie.pmb@bsi.ac.id ${ }^{2)}$,

nurul.afif_bsi@yahoo.com ${ }^{3)}$

\section{ABSTRAK}

Kebijakan pada kualitas pelayanan dan harga tiket dapat mempengaruhi loyalitas pelanggan jasa PT KAI Commuter Jabodetabek. Penelitian ini bertujuan menganalisis pengaruh kualitas pelayanan dan harga tiket terhadap loyalitas pelanggan jasa PT KAI Commuter Jabodetabek, baik secara simultan maupun parsial. Metode penelitian menggunakan metode kuantitatif yang bersifat deskriptif dan verifikatif dengan ukuran populasi 100 responden dengan teknik sampling. Pengolahan data menggunakan analisis regresi linear berganda dan koefisien determinasi pada taraf signifikan 5\%. Teknik pengumpulan data menggunakan teknik observasi, wawancara dan kuesioner. Hasil penelitian menunjukkan besarnya pengaruh kualitas pelayanan dan harga tiket terhadap loyalitas pelanggan jasa PT KAI Commuter Jabodetabek sebesar 31.9\%, model dapat dijalankan dan sisanya (68.1\%) tidak dapat dijalankan oleh variabel lainnya yang tidak diteliti. Kualitas pelayanan memberikan pengaruh yang lebih besar dibandingkan dengan harga tiket terhadap loyalitas pelanggan. 


\section{PENDAHULUAN \\ Latar Belakang}

Kelangsungan hidup sebuah perusahaan sangat tergantung pada kepuasan para konsumennya. Pertumbuhan tersebut selain diakibatkan oleh pertumbuhan jenis jasa yang sudah ada sebelumnya, juga disebabkan oleh jasa yang baru sebagai akibat dari tuntutan dan perkembangan teknologi. Perkembangan dan kemajuan teknologi pada akhir-akhir ini telah membawa perubahan signifikan dalam penerapan pelaksanaan bisnis di setiap perusahaan, juga telah mengubah cara perusahaan dalam menjalankan bisnisnya serta mengubah perilaku, preferensi dan tuntutan konsumen.

PT Kereta Api Indonesia (Persero) merupakan Badan Usaha Milik Negara (BUMN) sebagai satu-satunya perusahaan milik pemerintah yang menyediakan jasa transportasi kereta api di Indonesia juga tidak lepas dari sorotan masyarakat mengenai kualitas pelayanan yang diberikan. Kereta api menjadi salah satu modal transportasi penting yang ada di Indonesia. Poin penting dari jasa transportasi ini adalah kereta api dapat menjadi solusi dalam mengatasi masalah kemacetan di jalan raya. Selain itu kereta api yang merupakan salah satu mass transportation di Indonesia ini juga menawarkan ketepatan waktu (ontime) kepada konsumen karena melintas pada jalurnya sendiri dan dengan harga relatif terjangkau bagi konsumen. Demi mencapai kepuasan konsumen yang maksimum, maka perusahaan harus memperhatikan produk dan jasa yang dihasilkan, serta menyadari pentingnya kualitas layanan pada konsumen meskipun hal ini tidak mudah diimplementasikan oleh perusahaan.

Sebagian besar konsumen Commuter Line dari PT KCJ adalah konsumen masyarakat dari berbagai kelas, sehingga sangat dipentingkan kualitas pelayanan. Beberapa studi mengemukakan bahwa kualitas pelayanan memiliki hubungan yang erat dengan kepuasan pelanggan. Tjiptono, (2000) dan kualitas pelayanan memengaruhi kepuasan pelanggan dan pada akhirnya memengaruhi loyalitas. Sebagai ilustrasi, pertumbuhan volume penumpang kereta api di Indonesia cukup signifikan, yaitu jumlah volume penumpang kereta api tahun 2015 mencapai 221,73 juta penumpang. Raihan tersebut mengalami kenaikan 9,29\% bila dibandingkan tahun 2014 yang mencapai 202,88 juta penumpang. Dari volume tersebut angkutan Jabodetabek masih memberikan kontribusi terbesar, yaitu komersial jarak jauh (11,93\%). 88,07\% terhadap total volume angkutan kereta api penumpang di tahun 2015 dan sisanya berasal dari kontribusi kereta api.

\section{Tabel 1. Kinerja Transportasi PT KAI (Persero) Tahun 2011-2015 (dalam Jutaan} Penumpang)

\begin{tabular}{|c|c|c|c|c|c|c|}
\hline \multirow{2}{*}{ Uraian } & \multicolumn{5}{|c|}{ Tahun } \\
\cline { 2 - 6 } & $\mathbf{2 0 1 1}$ & $\mathbf{2 0 1 2}$ & $\mathbf{2 0 1 3}$ & $\mathbf{2 0 1 4}$ & $\mathbf{2 0 1 5}$ \\
\hline Penumpang & 207,16 & 203,13 & 191,69 & 202,88 & 221,73 \\
\hline $\begin{array}{c}\text { Penumpang } \\
\text { Jabodetabek }\end{array}$ & 130,63 & 124,29 & 110,82 & 134,09 & 158,34 \\
\hline $\begin{array}{c}\text { Penumpang non- } \\
\text { jabodetabek }\end{array}$ & 76,53 & 78,83 & 80,87 & 68,79 & 63,38 \\
\hline
\end{tabular}

Sumber: PT KCJ, diolah (2014)

Mempertahankan loyalitas pelanggan merupakan salah satu langkah baik yang dapat diterapkan oleh perusahaan untuk tetap dapat bersaing dan menguasai pangsa 
pasar. Demi terwujudnya maksud tersebut, maka PT KAI Commuter Jabodetabek diharapkan mampu menjaga perilaku ramah, efisien dan efektif dalam menyajikan produk/jasanya, sehingga dapat menumbuhkan kepercayaan dan kenyamanan dari pihak pelanggan. PT KAI Commuter Jabodetabek juga diharapkan dapat lebih mengetahui faktor-faktor apa sajakah yang dapat meningkatkan loyalitas pelanggan dan juga mengevaluasi dan memperbaiki faktor-faktor yang dapat menurunkan tingkat loyalitas pelanggan.

Faktor-faktor yang masih perlu dievaluasi dan diperbaiki oleh PT KAI Commuter Jabodetabek adalah masih seringnya terjadi keterlambatan perjalanan KRL yang disebabkan oleh gangguan sinyal maupun kurangnya infrastruktur rel kereta, penumpang yang berdesak-desakan di dalam rangkaian kereta pada jam-jam sibuk karena jumlah KRL yang tidak sesuai dengan jumlah penggunanya, serta AC yang tidak bekerja optimal, terutama saat kereta padat penumpang. Untuk itu PT KAI Commuter Jabodetabek diharapkan mencari solusi terbaik untuk permasalahanpermasalahan tersebut, sehingga dapat menghasilkan kinerja lebih baik demi tercapainya kepuasan pelanggan yang pada akhirnya diharapkan dapat menumbuhkan loyalitas pelanggan.

Penelitian yang dilakukan Akbar dan Parvez, (2009) pada pelanggan mobile communication di Bangladesh menghasilkan kesimpulan bahwa kepercayaan (trust) dan kepuasan pelanggan (customer satisfaction) mempunyai pengaruh positif dan signifikan terhadap loyalitas pelanggan (customer loyalty).

Zikmund (2003:72) menyatakan bahwa aspek yang mempengaruhi loyalitas adalah satifaction (kepuasan), emotional bonding (ikatan emosional), trust (kepercayaan), choice reduction and habit (kemudahan), dan history with the company (pengalaman terhadap perusahaan). Peran loyalitas bagi perusahaan terjawab oleh pendapat seorang ahli pemasaran, yaitu Kotler \& Keller (2006:57). Indikator loyalitas pelanggan) adalah Repeat Purchase (kesetiaan terhadap pembelian produk), Retention (Ketahanan terhadap pengaruh yang negatif mengenai perusahaan), referrals (mereferensikan secara total esistensi perusahaan). Ketiga indikator tersebut mengarah kepada besarnya volume penjualan, dan sangat berhubungan dengan kelangsungan hidup sebuah perusahaan dalam jangka panjang.

Dari pendapat beberapa ahli tersebut dapat disimpulkan bahwa loyalitas berhubungan dengan keberhasilan dan kelangsungan hidup perusahaan. Salah satu faktor yang berpengaruh pada loyalitas pelanggan adalah trust (kepercayaan). Dalam hal ini suatu produk melekat kualitas dan harga, maka kepercayaan (trust) dapat terbentuk apabila kedua variabel tersebut dapat memenuhi keinginan pasar.

\section{KAJIAN PUSTAKA}

\section{Teori-Teori Variabel Dependen}

Pearson (1999) mengemukakan bahwa terdapat enam prinsip loyalitas Pelanggan, antara lain:

1. Loyalitas itu menyangkut masalah Pelanggan yang berusaha untuk setia atau terbatasi oleh faktor-faktor seperti harga atau regulasi, sehingga tidak akan mengekspresikan kesetiaanya. Pelanggan mungkin akan setia pada perusahaan untuk satu jenis produk atau satu merek tertentu tidak pada produk lainnya. 
2. Loyalitas tidak dapat disebut sebagai akibat dan rendahnya harga, yang mana akan menyebabkan Pelanggan berpindah ke merek lain yang lebih murah. Harga yang istimewa bagi Pelanggan dapat menjadi hal penting untuk membangun hubungan dengan kesetiaan Pelanggan.

3. Loyalitas memerlukan keterlibatan positif dan Pelanggan bukan pembelian rutin yang sederhana. Kesetiaan Pelanggan lebih dan sekedar kepuasan Pelanggan sekalipun kepuasan merupakan hal

\section{Teori-Teori Variabel Independen}

Dalam sub-bab ini peneliti akan dipaparkan teori yang berkaitan dengan Variabel Independen dalam penelitian ini, yakni Kualitas Layanan, Harga dan Kepuasan Pelanggan.

\section{Kualitas Layanan}

Berry dan Parasuraman yang dikenal sebagai service quality atau biasa disebut dengan SERVQUAL (Kotler dan Keller, 2007:56), berikut :

1. Reliability (kehandalan)

Kemampuan menyelenggarakan jasa yang akan diandalkan, akurat dan konsisten, dengan kata lain kemampuan suatu perusahaan untuk memberikan pelayanan sesuai yang dijanjikan secara akurat dan terpercaya, kinerja harus sesuai dengan harapan pelanggan yang berarti ketepatan waktu, pelayanan yang sama, untuk semua pelanggan tanpa kesalahan, sikap yang simpatik, dan dengan akurasi tinggi.

2. Responsiveness (daya tanggap)

Kemampuan untuk membantu atau melayani konsumen dengan cepat atau kemampuan untuk membantu dan memberikan pelayanan responsif dan tepat kepada pelanggan, dengan penyampaian informasi jelas. Membiarkan konsumen menunggu tanpa adanya suatu alasan yang jelas menyebabkan persepsi yang negatif dalam kualitas pelayanan.

3. Assurance (jaminan)

Mencakup pengetahuan, kesopanan dan pelayanan dari karyawan serta kemampuannya untuk membangun kepercayaan dan keyakinan bagi konsumen atau dapat diartikan pengetahuan, kesopansantunan, dan kemampuan para pegawai perusahan untuk menumbuhkan rasa percaya para pelanggan kepada perusahaan.

Dimensi jaminan ini merupakan gabungan dari dimensi:

a. Kompetensi (competence)

Artinya meliputi keterampilan dan pengetahuan yang dimiliki oleh karyawan.

b. Kesopanan (courtesy)

Yang meliputi keramahan, perhatian, dan sikap para karyawan.

c. Kredibilitas (credibility)

Meliputi hal-hal yang berhubungan dengan kepercayaan kepada perusahaan seperti reputasi, prestasi, dan sebagainya.

4. Perhatian (Empathy)

Memberikan perhatian dan peduli kepada konsumen dapat juga dimaksudkan memberikan perhatian tulus dan bersifat individual atau pribadi yang diberikan kepada para pelanggan dengan berupaya memahami keinginan konsumen. Suatu 
perusahaan diharapkan memiliki pengertian dan pengetahuan tentang pelanggan, memahami kebutuhan pelanggan secara spesifik, serta memiliki waktu pengoperasian yang nyaman bagi pelanggan.

Dimensi empati ini merupakan penggabungan dari dimensi:

a. Akses

Kemudahan untuk memanfaatkan jasa yang ditawarkan perusahaan.

b. Komunikasi

Kemampuan melakukan komunikasi untuk menyampaikan informasi kepada pelanggan atau memperoleh masukan dari pelanggan.

c. Pemahaman kepada pelanggan

Usaha perusahaan untuk mengetahui dan memahami kebutuhan dan keinginan pelanggan.

5. Tangibles (bukti langsung)

Kemampuan suatu perusahaan dalam menunjukkan eksistensinya kepada pihak eksternal. Penampilan dan kemampuan sarana dan prasarana fisik perusahaan dan keadaan lingkungan sekitarnya adalah bukti nyata dari pelayanan yang diberikan oleh pemberi jasa. Hal ini meliputi fasilitas fisik (gedung, gudang, dan lain sebagainya), perlengkapan dan peralatan yang dipergunakan (teknologi), serta penampilan pegawainya.

\section{Harga}

Menurut Kotler dan Amstrong (2008:289), harga adalah jumlah uang yang dibebankan untuk produk atau jasa atau jumlah nilai yang konsumen pertukarkan untuk manfaat dari memiliki atau menggunakan produk atau jasa tersebut. Pada umumnya, harga menjadi faktor utama yang mempengaruhi keputusan pembelian, namun saat ini faktor selain harga juga menjadi pengaruh penting dalam perilaku berbelanja konsumen.

\section{Kepuasan Pelanggan}

Kotler dan Keller (2007:102) mendefinisikan kepuasan pelanggan sebagai tingkat perasaan seseorang sebagai hasil dari perbandingan antara kenyataan dan harapan yang diterima sebuah produk dan jasa. Pelanggan yang puas biasanya tetap setia untuk waktu yang lebih lama, membeli lagi ketika perusahaan memperkenalkan produk baru dan memperbaharui produk lama, membicarakan hal-hal baik tentang perusahaan dan produknya kepada orang lain, tidak terlalu memperhatikan merek pesaing, tidak terlalu sensitif terhadap harga, menawarkan ide produk atau jasa kepada perusahaan, dan biaya pelayanannya lebih murah dibandingkan pelanggan baru, karena transaksi telah menjadi hal rutin (Kotler dan Keller, 2007:140).

\section{HASIL PENELITIAN DAN PEMBAHASAN Demografi Responden}

Responden dalam penelitian ini berjumlah 100 responden. Semua responden merupakan masyarakat kota Depok pengguna jasa angkutan PT KAI Commuter Jabodetabek yang melakukan keberangkatan maupun pemberhentian di stasiun Depok, 
stasiun Depok Baru, stasiun Pondok Cina dan stasiun Universita Indonesia. Karakteristik responden penelitian ini dapat dilihat pada Tabel 2.

Tabel 2. Karakteristik Responden

\begin{tabular}{|c|c|c|c|}
\hline \multicolumn{2}{|c|}{ Klasifikasi Responden } & Jumlah & Persentase (\%) \\
\hline \multirow[t]{3}{*}{ Jenis Kelamin } & Pria & 45 & 45 \\
\hline & Wanita & 55 & 55 \\
\hline & Jumlah & 100 & 100 \\
\hline \multirow{4}{*}{ Usia (Tahun) } & $15-25$ & 45 & 45 \\
\hline & $26-35$ & 29 & 29 \\
\hline & $36-70$ & 26 & 26 \\
\hline & Jumlah & 100 & 100 \\
\hline \multirow{4}{*}{$\begin{array}{l}\text { Pendidikan } \\
\text { terakhir saat ini }\end{array}$} & SMA & 13 & 13 \\
\hline & Diploma & 43 & 43 \\
\hline & S1 & 44 & 44 \\
\hline & Jumlah & 100 & 100 \\
\hline \multirow{5}{*}{$\begin{array}{l}\text { Pekerjaan saat } \\
\text { ini }\end{array}$} & Pelajar/Mahasiswa & 53 & 53 \\
\hline & PNS TNI/POLRI/ BUMN & 9 & 9 \\
\hline & Peg. Swasta/Wiraswasta & 13 & 13 \\
\hline & Pedagang \& Ibu Rumah Tangga & 25 & 25 \\
\hline & Jumlah & 100 & 100 \\
\hline \multirow{4}{*}{$\begin{array}{l}\text { Pengeluaran per } \\
\text { bulan untuk } \\
\text { transportasi }\end{array}$} & $\leq 250.000,00$ & 15 & 15 \\
\hline & $\geq 250.000,00-500.000,00$ & 60 & 60 \\
\hline & $>500.000,00-1.500 .000,00$ & 25 & 25 \\
\hline & Jumlah & 100 & 100 \\
\hline \multirow{5}{*}{$\begin{array}{l}\text { Lama } \\
\text { menggunakan } \\
\text { jasa KRL }\end{array}$} & $<6$ bulan & 7 & 7 \\
\hline & $\geq 6-12$ bulan & 31 & 31 \\
\hline & $\geq 1-10$ tahun & 41 & 41 \\
\hline & $>10-20$ tahun & 21 & 21 \\
\hline & Jumlah & 100 & $100 \%$ \\
\hline
\end{tabular}

Sumber : Hasil Penelitian, diolah (2014)

Tabel 3. Statistik Deskriptif

Descriptive Statistics

\begin{tabular}{|l|r|r|r|r|r|}
\hline & \multicolumn{1}{|c|}{ N } & Minimum & Maximum & \multicolumn{1}{c|}{ Mean } & Std. Deviation \\
\hline Pelayanan & 100 & 117.00 & 195.00 & 155.1900 & 20.04071 \\
\hline Harga & 100 & 28.00 & 50.00 & 38.4500 & 4.77234 \\
\hline Kepuasan & 100 & 21.00 & 40.00 & 32.4200 & 4.28335 \\
\hline Loyalitas & 100 & 31.00 & 55.00 & 43.5800 & 5.67322 \\
\hline Valid N (listwise) & 100 & & & & \\
\hline
\end{tabular}

Sumber : Hasil Penelitian, diolah (2014) 


\section{Uji Persyaratan Analisis \\ Uji Normalitas Data}

Uji Normalitas dalam penelitian bertujuan menguji data variabel dependen (terikat) dan variabel independen (bebas) keduanya terdistribusi atau tersebar secara normal atau tidak. Hal ini dapat dilihat dari grafik histogram maupun grafik normal $P$ $P$ Plot of Regression Standardized. Jadi dengan kata lain uji kolmogorov smirnov merupakan uji beda antara data yang diuji normalitasnya dengan data normal baku. Seperti pada uji beda lainnya, jika signifikansi di bawah 0.05 , dinyatakan tidak normal dan sebaliknya jika signifikansi di atas 0.05 maka dinyatakan normal. Berikut hasil uji normalitas data dengan uji kolmogorov smirnov semua variabel penelitian.

\section{Uji Homogenitas}

Uji Homogenitas dimaksudkan untuk menunjukkan dua atau lebih kelompok data sampel berasal dari populasi yang sama. Uji homogenitas termasuk syarat untuk melakukan analisis regresi yang membutuhkan pengelompokan berdasarkan variabel terikatnya dengan variasi yang sama.

\section{Uji Korelasi}

Uji Korelasi merupakan teknik statistikyang digunakan untuk menguji ada tidaknya hubungan timbal balik dari dua variabel atau lebih. Besar kecilnya hubungan antara dua variabel dinyatakan dalam bilangan yang disebut Koefisien korelasi.

Tabel. 4. Uji KorelasiVariabel Kualitas Layanan(XI), Harga(X2), Kepuasan Pelanggan(X3) dan Loyalitas Pelanggan(Y)

\section{Correlations}

\begin{tabular}{|c|c|c|c|c|c|}
\hline & & Pelayanan & Harga & Kepuasan & Loyalitas \\
\hline & Pearson Correlation & 1 & $.789^{* *}$ & $.846^{* *}$ & $.522^{\text {*** }}$ \\
\hline Pelayanan & Sig. (2-tailed) & & .000 & .000 & .000 \\
\hline & $\mathrm{N}$ & 100 & 100 & 100 & 100 \\
\hline & Pearson Correlation & $.789^{* * *}$ & 1 & $.828^{* *}$ & $.332^{\text {*** }}$ \\
\hline Harga & Sig. (2-tailed) & .000 & & .000 & .001 \\
\hline & $\mathrm{N}$ & 100 & 100 & 100 & 100 \\
\hline & Pearson Correlation & $.846^{* * *}$ & $.828^{* *}$ & 1 & $.487^{\text {*** }}$ \\
\hline Kepuasan & Sig. (2-tailed) & .000 & .000 & & .000 \\
\hline & $\mathrm{N}$ & 100 & 100 & 100 & 100 \\
\hline & Pearson Correlation & $.522^{* * *}$ & $.332^{* * *}$ & $.487^{* *}$ & 1 \\
\hline Loyalitas & Sig. (2-tailed) & .000 & .001 & .000 & \\
\hline & $\mathrm{N}$ & 100 & 100 & 100 & 100 \\
\hline
\end{tabular}

**. Correlation is significant at the 0.01 level (2-tailed).

Sumber : Hasil Penelitian, diolah (2014) 
Dalam penelitian ini analisis regresi linear berganda dilakukan dengan bantuan program SPSS 17, denganseperti dimuat pada Tabel 5

\section{Tabel 5. Uji Regresi Linear Berganda}

Coefficients $^{\mathrm{a}}$

\begin{tabular}{|ll|r|r|r|r|r|}
\hline \multirow{2}{*}{ Model } & \multicolumn{2}{|c|}{$\begin{array}{c}\text { Unstandardized } \\
\text { Coefficients }\end{array}$} & $\begin{array}{c}\text { Standardized } \\
\text { Coefficients }\end{array}$ & \multicolumn{2}{|c|}{} \\
\cline { 2 - 7 } & \multicolumn{1}{|c|}{ B } & Std. Error & \multicolumn{1}{c|}{ Beta } & \multicolumn{1}{c|}{ t } & \multicolumn{1}{c|}{ Sig. } \\
\hline \multirow{2}{*}{ (Constant) } & 1.206 & .373 & & 3.232 & .002 \\
& Kualitas Layanan & .256 & .321 & .202 & .797 & .427 \\
& .031 & .330 & .025 & .094 & .925 \\
& Harga & .449 & .129 & .474 & 3.482 & .001 \\
\hline
\end{tabular}

a. Dependent Variable: Loyalitas Pelanggan

Sumber : Hasil Penelitian, diolah (2014)

Berdasarkan hasil pengolahan data pada tabel 3.4. diperoleh koefisien regresi (a) sebesar 1.206, koefisienb1 sebesar 0.256, koefisien b2 sebesar 0.031 dan koefisien b3 sebesar 0.449. Sehingga dapat diperoleh model persamaan regresinya sebagai berikut :

$\mathrm{Y}=1.206+0.256 \mathrm{X}_{1}-0.031 \mathrm{X}_{2}+0.449 \mathrm{X}_{3}$

Intrepretasi dari persamaan regresi linier tersebut adalah sebagai berikut:

1. $\mathrm{Y}=$ Loyalitas Pelanggan

Variabel terikat yang nilainya akan diprediksi oleh variabel bebas. Pada penelitian ini variabel terikat adalah Loyalitas Pelanggan, nilainya akan diprediksi oleh variabel Kualitas Layanan $\left(\mathrm{X}_{1}\right)$, Harga $\left(\mathrm{X}_{2}\right)$, dan Kepuasan Pelanggan $\left(\mathrm{X}_{3}\right)$.

2. Nilai Konstanta $=1.206$

Konstanta (a) sebesar 1.206menyatakan bahwa jika Kualitas Layanan, Harga, dan Kepuasan Pelanggan memiliki nilai nol maka Loyalitas Pelanggan mempunyai nilai sebesar 1.206.

3. $\mathrm{b}_{1}=0.256$

Koefisien regresi $\left(b_{1}\right)$ Sebesar 0.256 dengan tanda positif berarti bahwa setiap kenaikan Kualitas Layanan satu satuan maka variabel Loyalitas Pelanggan (Y) akan naik sebesar 0.256 dengan asumsi bahwa variabel bebas yang lain dari model regresi adalah tetap.

1. $\mathrm{b}_{2}=0.031$

Koefisien regresi $\left(b_{2}\right)$ sebesar 0.031 dengan tanda negatif berarti bahwa setiap kenaikan Harga satu satuan maka variabel Loyalitas Pelanggan (Y) akan turun sebesar 0.031 dengan asumsi bahwa variabel bebas yang lain dari model regresi adalah tetap.

5. $\mathrm{b}_{3}=0.449$

Koefisien regresi $\left(b_{3}\right)$ sebesar 0.449 dengan tanda positif berarti bahwa setiap kenaikan Kepuasan Pelanggan satu satuan maka variabel Loyalitas Pelanggan (Y) akan naik sebesar 0.449 dengan asumsi bahwa variabel bebas yang lain dari model regresi adalah tetap. 
Tabel 6. Uji t Coefficients ${ }^{\mathrm{a}}$

\begin{tabular}{|r|r|c|r|r|}
\hline \multicolumn{2}{|c|}{$\begin{array}{c}\text { Unstandardized } \\
\text { Coefficients }\end{array}$} & $\begin{array}{c}\text { Standardized } \\
\text { Coefficients }\end{array}$ & \multicolumn{2}{|c|}{} \\
\hline \multicolumn{1}{|c|}{ B } & Std. Error & Beta & \multicolumn{1}{|c|}{$\mathrm{t}$} & \multicolumn{1}{|c|}{ Sig. } \\
\hline 1.206 & .373 & & 3.232 & .002 \\
.256 & .321 & .202 & .797 & .427 \\
.031 & .330 & .025 & .094 & .925 \\
.449 & .129 & .474 & 3.482 & .001 \\
\hline
\end{tabular}

Dependent variabel: loyalitas pelanggan

Sumber : Hasil Penelitian, diolah (2014)

1. Harga $\left(\mathrm{X}_{2}\right)$

Variabel Harga $\left(\mathrm{X}_{2}\right)$ memiliki nilai signifikansi 0,094. Nilai t hitung berada di area penolakan Ho. Dengan demikian pengujian Ho ditolak dan $\mathrm{H}_{1}$ diterima. Hal ini memperlihatkan bahwa Harga $\left(\mathrm{X}_{2}\right)$ berpengaruh signifikan negatif terhadap Kualitas Layanan (Y) dan Harga memiliki hubungan berlawanan arah dengan loyalitas pelanggan dan besar pengaruhnya sebesar 0.031. Artinya, jika Harga naik maka Loyalitas Pelanggan akan turun, dan jika Harga turun Loyalitas Pelanggan akan naik.Hal ini senada dengan penelitian yang dilakukan oleh Melysa E. Pongoh (2011) dalam jurnalnya yang berjudul Kualitas Pelayanan, Kualitas Produk, dan Harga Pengaruhnya terhadap Loyalitas Pelanggan Kartu AS Telkomsel di Kota Manado. Menurut penelitian tersebut, besar koefisien variabel harga adalah sebesar 0,025 yang artinya setiap penurunan harga sebesar satu satuan akan mengakibatkan kenaikan loyalitas pelanggan sebesar 0,025.

2. Kepuasan Pelanggan $\left(\mathrm{X}_{3}\right)$

Variabel Kepuasan Pelanggan $\left(\mathrm{X}_{3}\right)$ memiliki nilai signifikansi 0,001. Nilai Sig $\mathrm{t}<5$ $\%(0,000<0,05)$. T hitung 3.482>0.677 (t tabel).Maka, pengujian Ho ditolak dan $\mathrm{H}_{1}$ diterima. Hal ini memperlihatkan bahwa Kepuasan Pelanggan $\left(\mathrm{X}_{3}\right)$ berpengaruh signifikan terhadap Loyalitas Pelanggan (Y) dan Kepuasan Pelanggan memiliki hubungan searah dengan Loyalitas Pelanggan dan besar pengaruhnya sebesar 0,449.

Tabel 7. Uji F

ANOVA $^{\text {b }}$

\begin{tabular}{|c|c|c|c|c|c|c|}
\hline & Model & $\begin{array}{l}\text { Sum of } \\
\text { Squares }\end{array}$ & df & $\begin{array}{c}\text { Mean } \\
\text { Square }\end{array}$ & $\mathbf{F}$ & Sig. \\
\hline \multirow[t]{3}{*}{1} & Regression & 11.447 & 3 & \multirow{3}{*}{$\begin{array}{r}3.816 \\
.145\end{array}$} & \multirow[t]{3}{*}{26.233} & \multirow[t]{3}{*}{$.000^{\mathrm{a}}$} \\
\hline & Residual & 13.964 & 96 & & & \\
\hline & Total & 25.411 & 99 & & & \\
\hline
\end{tabular}

a. Predictors: (Constant), Kepuasan Pelanggan, Kualitas Layanan, Harga

b. Dependent Variable: Loyalitas Pelanggan

Sumber : Hasil Penelitian, diolah (2014) 
Berdasarkan hasil perhitungan yang dapat dilihat pada tabel 3.6. menunjukkan Signifikansi F = 0.000. Jadi Sig F $<5 \%(0.000<0.05)$ dan F hitung $>3.96$ (F tabel), dengan demikian $\mathrm{H} 0$ diolak dan $\mathrm{H}_{1}$ diterima yang berarti bahwa secara bersama-sama variabel $\mathrm{X}_{1}, \mathrm{X}_{2}, \mathrm{X}_{3}$ mempunyai pengaruh yang signifikan terhadap variabel $\mathrm{Y}$. Jadi terbukti bahwa variabel Kualitas Layanan, Harga, dan Kepuasan Pelanggan berpengaruh secara simultan terhadap Loyalitas Pelanggan.

Dengan demikian hasil penelitan ini sebagai berikut:

1. Kulitas Layanan $\left(\mathrm{X}_{1}\right)$ berpengaruh terhadap Loyalitas Pelanggan $(\mathrm{Y})$

2. Harga $\left(\mathrm{X}_{2}\right)$ berpengaruh signifikan terhadap Loyalitas Pelanggan (Y)

3. Kepuasan Pelanggan $\left(\mathrm{X}_{3}\right)$ berpengaruh signifikan terhadap Loyalitas Pelanggan $(\mathrm{Y})$

4. Kualitas Layanan, Harga, dan Kepuasan Pelanggan berpengaruh signifikan secara simultan terhadap Loyalitas Pelanggan (Y).

\section{KESIMPULAN}

Dari pembahasan yang telah diuraikan pada bab-bab sebelumnya, penulis mengambil kesimpulan bahwa terdapat hubungan positif antara variabel kualitas produk dan penilaian harga terhadap kepercayaan pelanggan akan memberikan kualitas layanan terbaik, mampu mempertahankan citra perusahaan, memberikan kepuasan pelanggan, dan dapat mempertahankan pelanggan untuk tidak pindah keperusahaan lain.

Penelitian dan pengujian terhadap variabel-variabel yang mempengaruhi kepuasan pelanggan untuk meningkatkan loyalitas pelanggan PT.KAI (commuter) Jabodetabek pada stasiun Depok.

Berdasarkan hasil analisis dan pembahasan sehubungan dengan hasil penelitian ini dapat disimpulkan sebagai berikut:

1. Persepsi Terdapat sembilan atribut kualitas pelayanan yang dianggap paling penting oleh konsumen PT KAI Commuter Jabodetabek adalah sebagai berikut: kemudahan menjangkau stasiun), ketersediaan informasi, kemudahan memperoleh informasi yang jelas, kemampuan petugas dalam melaksanakan pekerjaannya, ketersediaan asuransi, kemampuan petugas memberikan informasi, kesediaan karyawan untuk melayani, kebersihan stasiun, Atribut ketersediaan alat untuk informasi rute perjalanan dan posisi kereta. Kualitas Layanan secara parsial berpengaruh positif terhadap Loyalitas PelangganPengguna Jasa PT. KAI Commuter Jabodetabek khususnya pengguna layanan di Stasiun Depok, Stasiun Depok Baru, Stasiun Pondok Cina dan Stasiun Universitas Indonesia.Artinya, jika Kualitas Layanan naik maka Loyalitas Pelanggan pun naik, dan sebaliknya.

2. Harga secara parsial berpengaruh negatif terhadap Loyalitas PelangganPengguna Jasa PT. KAI Commuter Jabodetabek.Artinya, jika Harga naik maka Loyalitas Pelanggan akan turun, dan sebaliknya.

3. Kepuasan Pelanggan secara parsial berpengaruh positif terhadap Loyalitas PelangganPengguna Jasa PT. KAI Commuter Jabodetabek.Artinya, jika Kepuasan Pelanggan naik maka Loyalitas Pelanggan pun naik, dan sebaliknya.

4. Kualitas Layanan, Harga, dan Kepuasan Pelanggan secara simultan berpengaruh positif terhadap Loyalitas PelangganPengguna Jasa PT. KAI Commuter Jabodetabek. 
Syahrial Addin ${ }^{1)}$, Putie Maharani Basa ${ }^{2)}$, Nurullah Sururi Afif ${ }^{3)} /$ JMM Online Vol . 2 No.5 September (2018) 536-547

5. Kualitas Layanan memiliki pengaruh paling besar terhadap Loyalitas Pelangganpengguna jasa PT. KAI Commuter Jabodetabek, alasannya karena Kualitas Layanan memiliki nilai yang paling besar jika dibandingkan dengan variabel Harga dan Kepuasan Pelanggan.

\section{DAFTAR PUSTAKA}

Akbar, M.M., and Parvez, N. 2009. Impact of Services Quality, Trust, and Customer Satisfaction on Customer Loyalty, ABAC Journal, Vol. 29, No. 1, pp. 24-38.

Arikunto, Suharsimi. 2006. Prosedur Penelitian Suatu Pendekatan Praktik. Jakarta: Rineka Cipta.

Alma, Buchari. 2005. Manajemen Pemasaran dan Pemasaran Jasa. Bandung: Alfabeta.

Bloemer, and Gaby O.S 2002, "Store Satisfaction and Store Loyalty Explained by Customer and Store Related Factors," Journal of Customer Satisfaction, Dissatisfaction and Complaining Behavior, ABI/INFORM Global, 15.

Ferdinand, Augusty. 2006. Structural Equation Modeling dalam Penelitian Manajemen. Semarang: Badan Penerbit Universitas Diponegoro.

Ghozali, Imam. 2006. Aplikasi Analisis Multivariate dengan Program SPSS. Semarang: Badan Penerbit Universitas Diponegoro.

Griffin, Jill.2006. Customer Loyalty:Menumbuhkan dan Mempertahankan Kesetiaan Pelanggan (alih bahasa oleh Dwi Kartini Yahya). Jakarta: Erlangga.

Griffin, Jill. 1998. Customer Loyalty, How To Earn It, How To Keep It. New York: Lexington Book.

Gronroos, Christian. 1990. Service Management and Marketing. Laxington Books, Massachusetts, Toronto. Hal. 37.

Hasan, Ali. 2008. Marketing. Jakarta: PT.Buku Kita

Hurriyati, R. 2008. Bauran Pemasaran dan Loyalitas Konsumen. Bandung: CV.Alfabeta.

Husein, Umar. 2005. Riset Pemasaran dan Perilaku Konsumen. Jakarta: PT Gramedia PustakaUtama.

Juliansyah, Noor. 2012. Metodologi Penelitian : Skripsi, Tesis, Disertasi dan Karya Ilmiah. Jakarta: Kencana.

Kheng, L.L., Mahamad, O., Ramayah, T., and Mosahab, R. 2010. The Impact of Service Quality on Customer Loyalty: A Study of Banks in Penang, Malaysia, International Journal of Marketing Studies, Vol. 2, No. 2, pp. 57- 66.

Kotler, Philip; et al. 2009. ManajemenPemasaran, Edisi 13 Jilid 1,Jakarta: Erlangga.

Kotler, Philip; et al. 2008.Prinsip-Prinsip Pemasaran (Alih Bahasa oleh Bob Sabran).Jilid 1.Edisike-duabelas. Jakarta: Erlangga.

Kotler, Philip; et al. 2007. Manajemen Pemasaran. Jilid 1 dan 2. Jakarta: PT Indeks.

Kotler, Philip; et al. 2000.Manajemem Pemasaran; Perspektif Asia, Buku 1, Yogyakarta: Penerbit Andi

Sambas Ali, Muhidin; et al. 2011. Dasar-dasar Metode Statistika untuk Penelitian. Bandung: Pustaka Setia.

Singarimbun, Masri dan Sofian Effendi. 1995. Metode Penelitian Survei. Jakarta : PT Pustaka LP3ES Indonesia. 
Pearson Steward. 1999. Building Brand Directly: Creating Business Value from Customer Relationship. Macmillam Business.

Riduwan. 2009. Metode dan Teknik Menyusun Tesis. Bandung: Alfabeta.

Santoso, Singgih. 2010. Statistik Parametrik, Konsep dan Aplikasi dengan SPSS. Jakarta: PT. Elex Media Komputindo.

Sugiyono, Dr. 2010. Metode penelitian Kuantitatif Kualitatif dan R\&D. Bandung: Alfabeta

Tjiptono, Fandy; et al. 2008. Pemasaran Strategik. Yogyakarta: CV. Andi Offset.

Tjiptono, Fandy. 2007. Manajemen Jasa. Edisi Keempat. Yogyakarta: Andi Offset.

Tjiptono, Fandy. 2006. Pelayanan Jasa. Yogyakarta: Penerbit Andi.

Zeithaml, Valarie A., Mary Jo Bitner \& Dwayne D. Gremler. 2009. Services Marketing - Integrating Customer Focus Across The Firm 5th Edition. New York: Mc. Graw Hill.

Zeithaml,Valarie A and Bitner, M.J. 2003. Service Marketing. New York: Tata Mc. Graw-Hill. Pp 85.

Riswandhi Ismail. 2012 dari PT. BPRS Syarikat Madani Batam dalam Jurnal Organisasi dan Manajemen yang menyimpulkan bahwa pengaruh Langsung Kualitas Layanan terhadap Loyalitas Nasabah

Yuda Ramadani. 2010 dalam jurnalnya yang berjudul Pengaruh Kualitas Pelayanan, Harga dan Kepuasan Pelanggan terhadap Loyalitas Pelanggan (Studi pada PT. TIKI Jalur Nugraha Ekakurir Agen Galunggung Kota Malang) 